\title{
Editorial - Ethics and Politics in the Philosophy of Management
}

\author{
Paul Griseri ${ }^{1}$
}

Published online: 2 June 2016

(C) Springer International Publishing AG 2016

The contributions in this issue are, in the main, concerned with ethical and/or political themes. It should not be a surprise that ethics and social theory appear frequently in the pages of journals concerned with the fundamentals of management. The whole project of philosophising about management is to understand its underpinnings, in terms of management as a collection of practices, as connecting a series of beliefs, and as one of the mechanisms by which modern society sustains itself. Unless and until we reach the condition where all economically significant activity is carried on via automation (and it is difficult to understand how that could happen unless the human race were relegated to a state of inertia) management is essentially a social activity. So any enquiry into management is implicitly or explicitly an enquiry into social relationships, which in turn requires some form of social theoretic perspective.

This immediately raises the question as to whether all and any social theory perspectives are appropriate and relevant to an understanding of the fundamentals of management. One standard view is that the study of management is intended to identify and explain the various ways in which humans, both individually and collectively, behave in relation to organised economic activity, the intention being that this will enable organisations to achieve their aims with greater efficiency and effectiveness.

One potential counter to this position is it is essentially political: on this view, management theory has evolved out of the desire of the developed West to maintain their levels of productivity and growth, and thereby (though whether this is the intention or not is a moot point) consolidate the dominance of those early developed economies and the mega-corporations that form their vanguard, over the rest of the global economy. According to this approach, ideas such as the quest for 'productivity' or methods for achieving 'quality' are really ciphers for an intent to maintain the relative ascendancy of western firms over those of other countries.

Another alternative, building on this last point, is that management thinking is a form of ideology - that the language and assumptions that inform and structure fields such as marketing and finance are intrinsically based on a conception of organised economic activity as

Paul Griseri

p.griseri@mdx.ac.uk

1 Middlesex University, London, UK 
conforming to a specific version of capitalism. The charge that much US-generated strategic theory is covertly neo-liberal in outlook reflects this.

Habermas' version of critical theory goes one step further along this trend of thinking, as it embodies the idea that various approaches to management ideas reflect distinct kinds of human need - to control nature, to co-ordinate with others, and to liberate ourselves, with an emphasis on the last of these as being the capstone that enables us to fully understand the other forms of knowledge. On this approach, the extrapolation of private sector corporatism to become a model for the management of other forms of organisation (such as public service) represents a constraint on our thinking that is only freed by a recognition of its political-social theoretic nature.

Arguably, all of these approaches adopt something akin to an implicit existentialist-style position - that the fact of management is prior to its essence, what it means, and so the job of explanation is less to construct management theoretically as to show how we may accommodate it to our human natures. But some very basic questions remain: when does a collection of humans become an organisation? which activities within collectives count as managerial? which events causally linked to an organisation count as its actions? And behind these is a question implicit in the idea of management as intrinsically social: what kinds of general social arrangements are necessary, or sufficient, for organisations, as we currently understand them to exist and flourish?

The contents of this issue do not attempt directly to answer any of these questions - quite properly, as they are beyond the scope of a journal article. However, in their various ways they provide insights that pertain to these bigger questions.

The paper of Ricardo Rovira and Domenec Melé on political wisdom draws on a theme that only occasionally appears in discussions of organisational management, namely an echo of political theory (which deals with the state and society) in organisations, which have some of the same characteristics: members, boundaries, authority and power. Of particular interest here is the pivotal question of whether a modern corporation is better thought of as political or regal. Beyond the analogy between corporation and state, the authors make clear that corporations sit within society, not alongside it. Hence there is a concept of the 'common good' which goes beyond what is good for a corporation, however the latter may interpret its goals. There are clear normative implications of this approach - not the least being that it is out of place for firms to attempt to subvert or overcome the fairly expressed will of a nation by using their corporate muscle.

The article by Cristina Neesham and Mark Dibben follows modern scholarship that recognises the extent to which Adam Smith was no simple free-marketeer of the modern neo-liberal tradition. Making an intriguing link with process philosophy, they demonstrate direct linkages between Smith's social theory, which was strongly rooted in a conception of community, with Marx's theory of class and class conflict. From this they recommend that business management should pay more attention to the manner in which social relationships, especially class-based ones, play out in dealings with different stakeholders. Here again we see the idea of management as echoing social structure.

One of the difficulties with dialogue between those who support the current market-oriented social arrangements and those who advocate some kind of change is the frequent divergence at the level of basic ethical theories. Much modern political economic thinking derives its support ultimately from consequentialist, or more specifically utilitarian, ethical theory. However, many critics of approaches such as neo-liberalism adopt Kantian or virtue-ethical perspectives. The result is that even well-grounded philosophical critiques of modern political economy rarely find favour with policy makers, who are often reared on a diet of utilitarian argument. Duane Windsor tackles this issue head on, arguing that there is a common core to morality that may be found in consequential, Kantian and virtue-ethical approaches. This, he argues, is 
grounded in a principle of 'first no harm without acceptable justification'. Whilst there may be differences in how 'acceptable justification' might be construed, this forms a basis for comparing business decisions, economic rationality, and even government policies relating to business. Windsor argues that this becomes the foundation for what he calls a moral science of business ethics - understanding motives, actions, and outcomes in the light of their relation with the 'first no harm' principle. Although towards the end the paper notes the differences between a moral science of business ethics and one of individual ethics, these are based, not in principles but in the variations between collective and singular actions and motives.

These papers so far discuss groups, firms, classes, collectives, and the common good as wholes. It is not a criticism of them that they look at these entities as if they were units without internal differentiation. Still, one pre-eminent feature of humanity is that any collection of people includes very many different types, even when they sublimate such differences for the sake of the collective. Mortaza Zare looks instead at differences within organisation - specifically the issue of deviance. Drawing on Heideggerian ideas, he argues that deviance is in part linked to the failure of the everyday to allow individuals to express their authentic individuality. He argues that practices such as story-telling and narrative can help develop a shared understanding authenticity, as a basis for managing and reducing deviance. Of course, some might argue that a certain level of deviance is desirable, for creation or for critique, but Zare's argument relates to deviance where it functions harmfully, for the individual or for the organisation.

At first sight Julian Freidland's paper on retrieving philosophy in management research looks to be an anomaly in this issue of the journal, as it does not explicitly address issues of social theory or ethics, instead being more an argument concerning the philosophy of management as science. However, we include it here as in several of the earlier papers there are hints in the direction of the nature of management knowledge: the idea of a 'moral science of business ethics' for example, or the issue of how organisational theory might echo political and social theory. Friedland is critical of the scientific pretensions of what we have earlier called the standard view of management, a view which all to often assumes a series of givens in relation to human behaviour, human normality, and human intention. Much of his argument is simply that too much is accepted without challenge, but beneath this is a presumption, on the part of some of those whom he critiques, that management as it is practised currently reflects a stable underpinning theoretical framework. Earlier I likened some approaches to management theory to existentialist philosophical strategy, where existence is taken as prior to essence. Whether or not such a perspective is adopted, it does not mean that critique, and the search for essence, is out of place, and one of the great merits of Friedland's paper is the role it presents for logic and argument as building blocks for theory, in contrast to the slavish, and often chaotically muddled, emphases on empirical methods for collecting data found not only in academic management literature but, perhaps worse, in the many and detailed volumes intended to train postgraduates - the knowledge-makers of the future-in research methodology.

We conclude with two book reviews, in keeping with the themes of this issue, one looks at a political treatment of a popular managerial concept, whilst the other discusses a collection of essays on the philosophical 'givens' of management.

\section{Paul Griseri}

Middlesex University May 2016 